\title{
THE BACTERIOLOGY OF DIPHTHERIA
}

INCLUDING SECTIONS ON THE HISTORY, EPIDEMIOLOGY AND PATHOLOGY OF THE DISEASE, THE MORTALITY CAUSED BY IT, THE TOXINS AND ANTITOXINS AND THE SERUM Disease. By F. Loeprler, M.D., LL.D., Arthur Newsногме, M.D., F.R.C.P., F. B. Matiory, M.A., M.D., G. S. GrahaM-Sмтth, M.A. M.D., P.P.H., George Dean, M.D., Whluam H. Park, M.D. and Charles F. Bolduan, M.D.

\section{Edited by}

G. H. F. NUTTALL, M.D., Ph.D., So.D., F.R.S.,

Quiok Professor of Biology in the University of Cambridge, Fellow of Chriat's College,

AND G. S. GRAHAM-SMTTH, M.A., M.D., University Lecturer in Hygiene, Cambridge

Royal 8vo. Buckram. Pp. $x x+718$.

With 4 portraits and 16 plates. Price 25s. net.

"It is by far the most complete record of our present knowledge of this disease hitherto written in the English language.... There is nothing to say except praise for the editors, who have produced a mngnificent exposition of modern knowledge on this important disease-an exposition which must certainly take its place as the classical authority upon the subjeot." - Nature

"The mere enumerstion of the writers is a sufficient guarantee of the excellence of the work, and of the authority which it carries; whilst the articles are written in clear and good English, free, for the most part, from the technical terms which make many treatises on bacteriology difficnit and unprofitable to read. The articles are well harmonised, and the teaching in regard to difficult and debatable points is marked by moderation and common sense." - Athenaeum

\section{PARASITOLOGY}

\section{A SUPPLEMENT TO THE JOURNAL OF HYGIENE}

Edited by GEORGE H. F. NUTTALL, F.R.S., Quick Professor of Biology in the University of Cambridge, and A. E. SHIPLEY, F.R.S., Reader in Zoology, Cambridge.

The Journal of Hygiene having become nndnly burdened with papers dealing with the anatomy of mosquitoes, fleas, protozon and other parasites - of great importance in themselves - but having only an indireet relation to hygiene and preventive medieine, it is proposed in future to relegste all such papers to Parasitotogy.

Parasitology, though a supplement to the Journal of Hygiene, will be issued in the form of a separate yearly volume of four to five hundred pages. The parts will be issued when sufficient material has aceumulated. The first three volumes are now ready. The subseription price is E1. 1s. per volume (post-free), payable in advance; single numbers 7s. net. Subseribers to the Journal of Hygiene may obtain single numbers of Parasitology at the reduced price of 5s. net or may become subscribers at the reduced rate of $15 \mathrm{~s}$. Subseriptions may be sent to any Bookseller, or to Mn C. F. Crax, Masaarn, Cambriage University Press, Fetter Lane, London, E.C. A Prospectus will be sent on application. 


\section{(All rights reserved)}

Dudgeon, Leonard S. A Diphtheria-like Bacillus causing Cellulitis in the Region of a Spontaneous Fracture in a Case of Tabes Dorsalis . . . . . .

Hamul, J. M. On the Bleaching of Flour and the Addition of so-called "improvers" to Flour . . . . . .

Monier-Whltams, G. W. On the Chemical Changes produced in Flour by Bleaching

Drew, G. Harold. A Note on some Attempts to cause the Formation of Cytolysins and Precipitins in Certain Invertebrates.

Atrin, E. E. The Relation of the Reaction of the Culture Medium to the Production of Haemolysin. ( 1 Chart in text)

MorGan, H. DE R. Attempts to Reproduce the Typhoid-carrier State in the Rabbit. (With Plate III) . . . .

Browning, Carl H. and Wilson, G. Haswell, On the Alterations in Haemolytic Immune-body which occur during the Process of Immunisation . . . . . .

Südmersen, H. J. and Glenny, A. T. Immunity of Guinea-pigs to Diphtheria Toxin and its Effect upon the Offspring . .

Nankrvel, A. T. The Sand Filtration and Purification of Chalk Waters. (1 Chart). . . . . .

Dean, George. Suppurative Cholecystitis with Cholelithiasis in a Human "Carrier" of the Bacillus enteritidis of Gaertner .

Rankin, T. Thomson. A Medium for Bacillus diphtheriae (Potassium-sulphocyanide Neutral-red Glucose Serum) .

Coplans, Myer. Differential Media for Recognition of B. diphtheriae and Associated Organisms . . . .

Watker, Cranston. Upon the Inoculation of Materia Morbi through the Human Skin by Flea-bites . . . 290

Congress of Hygiene . . . . . . . . . 301

Publications Received . . . . . . . . . 307

The Journal of Hygiene is issued as material accumulates. A volume containing about 500 pages, with plates and figures, is issued annually.

Volumes I, II, and III (1901-3) complete. In Four Parts, paper covers, 15s. net per volume. Bound in buckram, 18s, $6 d$, net per volume.

Volumes IV, V, VI, VII, VIII, IX and X (1904-10) complete. In Parts, paper covers, 21s. net per volume. Bound in buckram, 25s. net per volume.

Papers for publication may be sent to Prof. Geo. H. F. NutralL, F.R.S., 3 Cranmer Road, Cambridge, or to the associate Editors. Other communications should be addressed to the University Press, Cambridge.

Papers forwarded to the Editors for publication are understood to be offered to the Journal of Hygiene alone, unless the contrary is stated.

Contributors receive fifty copies of their papers free. Additional copies may be had at cost price: these should be ordered when the final proof is returned.

The subscription price is 21.18 . per volume (post-free), payable in advance; single numbers 78 . net. (Plague Numbers, Vol. VI. no. 4 (not sold separately), Vol. VII. nos. 3 and 6 , and Vol. VIII. no. 2, Vol. X. no. 3, Price 6s. net each.) Subscriptions may be sent to any Bookseller, or to Mr C. F. CLAY, MANager, Cambridge University Press, Fetter Lane, London, E.C. 